Book Review

\title{
Weber Herlinger, Ilse. Dancing on a Powder Keg: Letters and Poems. Translated from the German by Michal Schwartz, with afterword by Ulrike Migdal, and Theresienstadt essay by Ruth Bondy. Charlottetown, PE and Jerusalem: Bunim and Bannigan and Yad Vashem, 2016.
}

\section{Reviewed by Anna Marie Anderson, North Central Texas College, TX, USA.}

Dancing on a Powder Keg, a collection of letters and poems written by Ilse Weber from 1933-1944, provides an account of her family's experience leading up to and during the Holocuast. Weber was a Czechoslovakian Jew, an author (standard publications and radio programs), a wife, and mother. She spent the majority of her life in her hometown, Witkowitz, near the Sudetenland. Through Weber's writing, the reader can see the slow and yet, after 1939, rapid descent into deadly anti-Semitism at the Sudetenland border.

The majority of the letters were written by Weber to her childhood pen pal Lilian von Löwenadler (who moved back and forth from her native Sweden to England), although a small portion of the letters were written by other family members or to other friends and acquaintances. Weber's immediate family consisted of her husband Willi and sons Hanuš and Tomáš (called Tommy). Usually, their comments were added to the end of her letters, but they occasionally wrote their own correspondence. Weber would also write to Lilian's husband James Treen and Lilian's mother Gertrude von Löwenadler (who lived in Sweden). The letters were not rediscovered in Treen's attic (Lilian died during the war) until 1977, whereupon they were received by Hanuš. He would not read them until 1989. The poems were written by Weber after she was sent with her husband and younger son Tommy to Theresienstadt in 1942. Before being sent to Auschwitz, Willi buried the poems and retrieved them after the war. Willi and Hanuš would be the only ones to survive the Holocaust. Ilse Weber and Tommy were gassed upon their arrival in Auschwitz sometime late in 1944. Willi never knew they had been sent to Auschwitz until after the war. He was moved to another camp and despite a history of chronic health problems survived. Hanuš was sent to live with Lilian and James Treen in London in May of 1939, he would spend most of the war with Gertrude (Lilian's mother) in Sweden. The rest of the family had intended to emigrate elsewhere or follow to London or Sweden; however, a series of lack of funds and travel passes

Women in Judaism: A Multidisciplinary e-Journal Volume 17 Number 2 (2020) 
kept them trapped in Czechoslovakia. Weber's letters fall into categories based on their content as the family's situation deteriorated.

The letters written from 1933-1937 consist of mainly information about the children, her husband, and her work mostly writing pieces for radio broadcasts. Overall, these letters expressed more of the typical concerns of a homemaker, however, Weber, her husband, and especially the children were often seriously ill. There are some mentions of anti-Semitism and she first directly used the word "Nazi" in a letter dated July 6, 1935. The family was able to move to a larger apartment (on December 25, 1935). Weber had regular radio contracts, and the family took short vacations although these were occasionally for health reasons.

In 1938 her letters began to change with the occupation of the Sudetenland, which was near her hometown where the family still lived. On February 13, 1938, she noted that the local school, for whom she wrote plays the children performed on the radio, no longer wanted to work with a Jewish woman. Her letter on March 14, 1938 first broached the possibility of sending the children, Hanuš and Tommy, to stay with Lilian and James in London, although this was phrased as a sort of holiday. Clearly Weber hoped tensions would settle and the boys would be able to return after a short period. It is also in this letter that her descriptions of her sons, specifically Hanuš, changed; no longer did she write that he was "naughty" (33) or of "his continual sickliness" (14). Instead, she explained that he was "well-behaved" (51) and "only gets a light cold" (52). It is clear from Weber's writing that she always adored her children and only complained as any mother does, yet her letters after 1938 focused more on the positives of motherhood and her children. It is clear she was trying to point out the best traits in her children (perhaps an unspoken fear Lilian would change her mind or like other non-Jewish friends suddenly betray their friendship). They are also the words of a mother realizing how quickly her children might be taken from her, albeit in 1938 she still believed such a separation would be temporary. She became increasingly worried as various issues prevented them from sending Hanuš to London. Weber discussed anti-Semitism more frequently and noted that her radio writing would not outlast the Nazis. Shortly before the annexation of the Sudetenland she wrote, "I decided, after reading your letters, to pack both children and travel to you! Willi has done me the favor and inquired at the travel agency, and it wouldn't be that 
expensive after all." (60) However, she quickly noted it would be too difficult to get through Germany, but still requested information on cost of living in Sweden.

The letters from 1939-1944 portray the swift changes brought on by Germany's expansion. On January 5, 1939, Weber wrote they were "caught in a mousetrap" (71) and told Lilian and James to come get the boys "if anything happens" (72). She wrote about possibly emigrating to Palestine or Sweden, that her husband had to close his collection agency, and trying to figure out a way to send one or both of her children to London. Members of Willi's family were being arrested by the Gestapo. Finally, in May of 1939 Hanuš was sent to London. Thereafter, Weber's letters were split between those to Lilian and those to Hanuš imploring him to provide her with every detail possible and reminding him to behave. In 1940, Ilse, Willi, and Tommy moved to Prague; curfews were instituted for Jews and they were restricted from parks and other areas. Although Tommy was finally healthy, Ilse and Willi were still frequently sick. Hanuš had gone to live with Lilian's mother, Gertrude, in Sweden and would remain with her until after the war. The letters from Weber became sparser in 1941 as the family had to move into a one room "apartment" and she took in various sewing jobs to provide for the family whenever Willi was too sick to work. In a letter dated December 17, 1941 she wrote to Hanuš, "perhaps that happy day will come" (162) when they would be reunited. It was the first hint that they may never see each other again. In February of 1942, the family was sent to Theresienstadt. The handful of letters from 1942-1944 were a mix of truth-Ilse worked in a children's sick ward, Willi worked in various jobs, and Tommy lived in the children's section - and assurances that everything was perfectly fine (a requirement to pass the censors). Weber sent her last letter in September of 1944, it ended "WE ARE HEALTHY. MUCH LOVE ILSE” (174).

Weber wrote a collection of poems while in Theresienstadt that offered a grim view of the camp she could not include in her letters. These poems dealt with issues such as deportation in The Way to Theresienstadt, a poem about a child praying to be sent to the sick ward in Little Tommy's Evening Prayer, and children who "escaped the musty walls" (194) by dying in Whooping Cough Children. She wrote about the separation of her family despite being in the same camp in Family Life and a letter to Hanuš that she could never send titled Letter to My Child. One of her last poems,

Transport to Poland, expressed her fear of being sent to Auschwitz, her fear would come true. Women in Judaism: A Multidisciplinary e-Journal Volume 17 Number 2 (2020) ISSN 1209-9392 
Willi was sent to Auschwitz in September of 1944 and Ilse and Tommy were sent sometime shortly after and did not survive.

Although the letters only provide the reader with one side of a conversation, they offer a startling view of the Holocaust. The majority of Holocaust memoirs were written by survivors (or immediate family members) and usually events were recorded after the war ended. Lilian was not Jewish, and she lived safely in London and Sweden where she could preserve the letters. Even when Holocaust survivors wrote diaries, poems, or songs in ghettos and concentration camps, the original papers were usually destroyed before long death marches began, then rewritten from memory later. Dancing on a Powder Keg is distinctive. The materials were written during the Holocaust and survived largely intact, sadly their author did not. However, Weber left behind an invaluable source on the Holocaust. The book joins notable works such as Rena Kornreich Gelissen's Rena 's Promise: A Story of Sisters in Auschwitz (written with Heather Dune Macadam) and Wilhelmina (Mina) Pächter's In Memory's Kitchen: A Legacy from the Women of Terezin. For academics, Dancing on a Power Keg offers a new source for researchers, yet it would also complement any course on the Holocaust (the poems might be used in a literature course) and portions are appropriate for a survey Western Civilization history course.

The spelling and variations Weber used for persons and places were retained, while this was often necessary to convey her tone, at times it can leave the reader confused. For example, Weber frequently refers to her oldest son Hanuš as Hannerle, Hans, or Hanni and her hometown as Witkowitz (German) or Vítkovice (Czech). The reader would have benefitted from a short guide in the beginning noting Weber's various spellings (the translator did mention the hometown) and listing frequently mentioned persons. Although some of these are clarified in the endnotes, it is difficult to follow the earlier letters until the reader becomes acquainted with Weber's writing style and spellings. The book includes a foreword by the translator Michal Schwartz, a short essay on “The World of Theresienstadt” by Ruth Body, and an afterword by Ulrike Migdal, which provides additional context, information on Weber's life, and how the sources came together for the book to be published.

Women in Judaism: A Multidisciplinary e-Journal Volume 17 Number 2 (2020) 